Research Paper

\title{
Absorption, distribution and accumulation of nitrogen applied at different phenological stages in southern highbush blueberry (Vaccinium corymbosum interspecific hybrid)
}

\author{
Maria A. Pescie ${ }^{a, *}$, Marcela P. Borda ${ }^{a}$, Daniela P. Ortiz ${ }^{a}$, Maria R. Landriscini ${ }^{b}$, Raul S. Lavado ${ }^{c}$ \\ ${ }^{a}$ Cátedra de Fruticultura, Facultad de Ciencias Agrarias, Universidad Nacional de Lomas de Zamora e Instituto de Investigación sobre Producción Agropecuaria, Ambiente \\ y Salud (IIPAAS-CIC), Ruta 4, Km. 2, (1836) Llavallol, provincia de Buenos Aires, Argentina \\ ${ }^{b}$ CERZOS-Departamento de Agronomía, Universidad Nacional del Sur, Bahía Blanca, provincia de Buenos Aires, Argentina \\ ${ }^{\mathrm{c}}$ Instituto de Investigaciones en Biociencias Agrícolas y Ambientales (INBA/CONICET-UBA), Facultad de Agronomía, Universidad de Buenos Aires, Av. San Martín 4453, \\ C1417DSE, Buenos Aires, Argentina
}

\section{A R T I C L E I N F O}

\section{Keywords:}

Southern highbush blueberry

Nitrogen distribution

Biomass

\begin{abstract}
A B S T R A C T
Southern highbush blueberry has an early harvesting and then a long period of vegetative growth until dormancy, compared to highbush and rabbiteye blueberries. Nitrogen requirements could be different because of this specific early harvesting. Absorption of ${ }^{15} \mathrm{~N}$ enriched ammonium sulfate was compared at five phenological stages from bud swell to pre-dormancy in two years old plants of the cultivars Star and ÓNeal. Plants grown in pots were irrigated with ammonium sulfate solution $\left({ }^{15} \mathrm{~N}\right)$. Five plants for each application date were excavated and separated in parts (roots, canes, leaves, flowers, fruits or floral buds). Samples were taken three weeks after application from bud swell to pre-harvest treatment, and three month after for post-harvest and pre-dormancy treatment. Each tissue were dried and weighed before and after, and analyzed for ${ }^{15} \mathrm{~N}$ content, $\mathrm{N}$ content and $\mathrm{N}$ \%....N\%, and in leaves were also determined macro and micro nutrients. Nitrogen fertilization at bud swell is effective, even for the ÓNeal cultivarthat present floral bud break in absence of leaves. Post-harvest fertilization contribute $\mathrm{N}$ for summer vegetativegrowth which would influence the floral buds development next year, Nitrogenstorage at this time would led to the improved floral behavior next year. Nitrogen losses risk is lower at post-harvestfertilization.
\end{abstract}

\section{Introduction}

Blueberry belongs to the Vaccinum genera, originated in south east (SE) Canada and North West (NW) USA. Its production started to be commercial at the end of XIX century, the crop reached world importance at the 1990 decade. Traditionally there were three groups of blueberries: highbush (HBB), rabbiteye (REB) and lowbush (LBB). By mid-1970a hybrid known as southern highbush blueberry (SHB) was obtained by intercrossing V. corymbosum, V. angustifolium, V. ashei, V. tenellum and $V$. darrowi (Lang, 1993). The traditional blueberries groups differ phenologically from the SHB, which has lower chilling requirement (200-500 h below $7.2^{\circ} \mathrm{C}$ ) to break floral buds dormancy, earlier fruit maturityin the season anda second vegetative growthon summer. This growth, from harvest to dormancy, isgenerated from spring growth vegetative buds.Commercially, most new varietieshave better fruit size and higher yield than theprevious blueberry groups (Lyrene and Williamson, 1997; Pescie and Lopez, 2007; Pescie et al., 2011a,b).
Additionally, HBB and REB differ from SHB plants because they bloom later in spring, flowering and budding at the same time or two to four weeks later. In these groups fruit mature at mid or late summer (Birkhold et al., 1992; Childers and Lyrene, 2006). Last years theSHB cultivarshave been widely cultivatedin temperate and warm-temperate zones, in USA and other productive areas in the world (Strik and Yarborough, 2005) but specially in theSouthern Hemisphere productive area, including Argentina (Kirschbaum and Rivadeneira, 2011).

All blueberries present a small and shallow root system with few root hairs, which is inefficient for nutrient absorption (Abbott and Gough, 1987). Besides, the crop requires specific soil conditions likepH between 4.5 and 5.5, high organic matter content, high porosity, moist but with good drainage (Williamson et al., 2006). Where the soil doesnot match those characteristics, blueberry is cultivated in raised beds with addition of peat, and/or other local organic materials to adapt the soils conditions to crop requirement. The low $\mathrm{pH}$ is attained and maintained using sulfuric acid and acid fertilizerslike ammonium

\footnotetext{
* Corresponding author.

E-mail addresses: marielespescie@yahoo.com.ar, pescie@agrarias.unlz.edu.ar (M.A. Pescie).
} 
sulfate. This acid media create a soil environment poorly adapted for the nitrification process (Sahrawat, 2008), generating ammonia accumulation in the soil (Sahrawat, 2008). Blueberries, unlikemost fruit crops, are more efficient absorbing ammonia than nitrates (Merhaut and Darnell, 1995; Percival and Privé, 2002).

In agronomic terms,nitrogen $(\mathrm{N})$ is the most important nutrient to maintain the plant vegetative growth, fruit development, flower bud induction and differentiation. Nitrogen fertilization during spring, especially with ammonia, increases $\mathrm{N}$ concentration in leaves, lead to robust primary branch and allow high yields (Hanson and Retamales, 1992; Hart et al., 2006). Blueberry cultivars grown up in cold climates, has lower $\mathrm{N}$ requirements than blueberries grown in warm climates (Williamson et al., 2006). SHB cultivars showing higher yields and different phenology than traditional blueberries, allow us to hypothesize that $\mathrm{N}$ demand may not only be higher but also can occurs at different moments of plant development. Then, the use of fertilization practices adapted to traditional varieties on the HSB cultivars could lead to inadequate and inefficient application of this nutrient, with negative economic and environmental consequences (Mailhol et al., 2001). Inadequate fertilization could cause $\mathrm{N}$ deficiency (Mailhol et al., 2001) or N excess in plants (Williamson et al., 2006). Crop yield could be negatively affected in both cases, and $\mathrm{N}$, especially the mobile nitrates could be lost from the soil with negative environmental effects (Retamales and Hanson, 1990; San Martino et al., 2014).Nitrogen absorption efficiency is low in fruit trees, where $\mathrm{N}$ recoveries areusually lower than 45\% (Mohadjer et al., 2001; Rempel et al., 2004). In HBB, Retamales and Hanson (1989), found recoveries of $32 \%$ of the applied $\mathrm{N}$ and Bañados et al. (2006a, 2006b) found $\mathrm{N}$ recoveries ranging from $22 \%$ to $43 \%$, depending on crop management and fertilization time and concentration. Thus, it is recommended for HHB to split $\mathrm{N}$ fertilization in two or three times at adequate phenological stages (Hanson and Retamales, 1992).

Before winter dormancy $\mathrm{N}$ is mobilized within the plant and stored mainly in roots and crown, in blueberry and other fruit crops (Tromp, 1983; Birkhold et al., 1992; Birkhold and Darnell, 1993; San-Martino et al., 2010). Stored nitrogen is used to sustain the next reproductive and vegetative growth. According to Throop and Hanson (1997) and Bañados et al. (2006a, 2006b) N absorption occurs in HBB only when leaves are in active growth; nitrogen demand is high from the petals fall to harvestandat the end of the vegetative period. $\mathrm{N}$ absorption decrease significantly when plants enter in dormancy. Vidal et al. (1999) found a similar pattern in rabbiteye blueberries, as well as Weinbaum et al. (1978) in plum and Conradie (1986) in grapevine. Unlike cultivars of other blueberry groups, most SHB cultivars present vegetative bud break two or three weeks after bloom. Floral bud break, flowering, fruit set and beginning of fruit development depend on stored nutrients (Tromp, 1983; Loescher et al., 1990).

In HBB plants, $\mathrm{N}$ from fertilizers was found in expanded leaves 15 days after its application, a week later $\mathrm{N}$ reacheditsmaximum concentration and then wasreduced significantly. Crown is the organ that storage most nitrogen (33\%), followed by roots (19.8\%) and leaves (16.8\%), and the fruits have the lower concentration (4.2\%) (Retamales and Hanson, 1989; Chuntanaparb and Cummings, 1980). HBB and REB fruits show higher $\mathrm{N}$ content after fruit setting but a later decreased as fruit grows and ripens (Birkhold et al., 1992; Tamada, 2000). Vidal et al. (1999) found in REB that content of $\mathrm{N}$ in the plant decrease from three weeks after bloom until harvest, but later begins to increase again.

To estimate $\mathrm{N}$ storage pools and $\mathrm{N}$ distribution in different organs, the utilization of ${ }^{15} \mathrm{~N}$ is the main method used in fruit trees (Kraimer et al., 2001). This procedure was used to study $\mathrm{N}$ dynamics in traditional blueberry varieties (Retamales and Hanson, 1989; Chuntanaparb and Cummings, 1980; Merhaut and Darnell, 1995). Due to the differences above explainedbetween the SHB and the other blueberry groups, the determination of the adequate moment of $\mathrm{N}$ application is important for SHB cultivars, especially those cultivated in the Southern
Hemisphere. Our objective was to identify the more convenient moments to apply $\mathrm{N}$ fertilizers from an agronomic and environmental point of view. Two SHB varieties of different phenology were studied, to determine $\mathrm{N}$ absorption throughout the year and its distribution and accumulation in different plant organs.

\section{Materials and methods}

A pot experiment was carried out in Llavallol $\left(34^{\circ} 46^{\prime} \mathrm{S} 58^{\circ} 24^{\prime} \mathrm{O}\right)$, Buenos Aires Province, Argentina. Two years old plants of SHB cultivars were used. The cultivars were ÓNeal (low to medium vigor, vegetative bud break tree weeks after bloom) and Star (high vigor and coincidentbloom and vegetative bud break). The experiment was carried outdoor using 10 liters pots under a frost protection mesh, to avoid potential spring frostdamage.The experiment was conducted as a completely randomized design with 5 treatments and 5 replications, where each plant was experimental unit. A mix of peat, perlite and soil (A horizon of a local Typic Argiudoll) was used as a substrate, with the $\mathrm{pH}$ kept in the range of 4.2 to 5.0. Plants were irrigated with distilled water and kept around field capacity, avoiding drainage leaking.

To satisfy crop $\mathrm{N}$ requirements, a solution of ammonia sulfate was applied following Troop and Hanson (1997) methodology. The solution contained $1.5 \%$ of ammonia sulfate $\left({ }^{15} \mathrm{~N} 98+\right.$ atom $\%$ Aldrich) and $98.5 \%$ of commercial ammonia sulfate. This solution was applied in both cultivars at the following phenological stages which representthe treatments: T1) atbud swell: $25 \%$ of flower bud breaks (August 13, 2014); T2) Fruit set: $50 \%$ of fruits set (October 4, 2014); T3) Pre-harvest: $15 \%$ of the fruits developing blue color (November 19, 2014); T4) Post-harvest: complete vegetative development (January13, 2015) and T5) Pre-dormancy: before plant goes on dormancy (April 3, 2015).

In order to allow ${ }^{15} \mathrm{~N}$ to reach different plant organs, plants of the treatments $\mathrm{T} 1$ to $\mathrm{T} 3$ were removed after 18 days of $\mathrm{N}$ application (September 3, October 22 and December 7 respectively). Plants of the treatments T4 and T5 were removed after 120 days of $\mathrm{N}$ fertilization (April 9 and August 23, respectively). Removed plants were taken into parts and roots, canes, leaves and flowers or fruits or buds were collected separately. Dry matter (DM) of each part DM was determined by drying samples in an oven at $60{ }^{\circ} \mathrm{C}$ until constant weight. The proportion of ${ }^{15} \mathrm{~N}$ was determined in all plant samples using optical emission spectrometry (International Atomic Energy Agency, 2001). The natural abundance of ${ }^{15} \mathrm{~N}$ for the commercial ammonia sulfate used to the dilute the tagged fertilizer was estimated as $0.366 \%$ (International Atomic Energy Agency, 2001).

Macro and micronutrients concentration in leaves taken at time of T3 were determined following standard techniques (Temminghoff, 2000): Total N was determined by Kjeldahl method, Phosphorus (P) by colorimetry previous acid digestion and potassium (K), calcium (Ca), magnesium (Mg), sulfur (S), copper ( $\mathrm{Cu})$, zinc ( $\mathrm{Zn})$, iron $(\mathrm{Fe})$ and manganese $(\mathrm{Mn})$ by atomic adsorption spectrometry previous acid digestion and boron (B) by a colorimetric technic. The percentage of $\mathrm{N}$ derived from the fertilizer (NdfF) in each tissue was calculated using the equation:

$\mathrm{NdfF}=$ atom $\%{ }^{15} \mathrm{~N}$ of plant sample - atom $\%{ }^{15} \mathrm{~N}$ natural abundance/ atom $\%{ }^{15} \mathrm{~N}$ fertilizer - atom $\%{ }^{15} \mathrm{~N}$ natural abundance

The fertilizer plant recovery was calculated using the equation:

Fertilizer plant recovery $(\%)=\mathrm{NdfF}$ plant/N fertilization $* 100$

Data were statistically analyzed by ANOVA using SAS 9.4 (2012). The analysis was performed separately for each cultivar across treatments (T1 to T5). Additionally, each tissue was analyzed separately for each treatment to test differences in tissue DM, N content and NdfF. In all cases a Duncan test ( $p$-value $\leq 0.05$ ) was used as the multiple comparison procedureto separate means. 


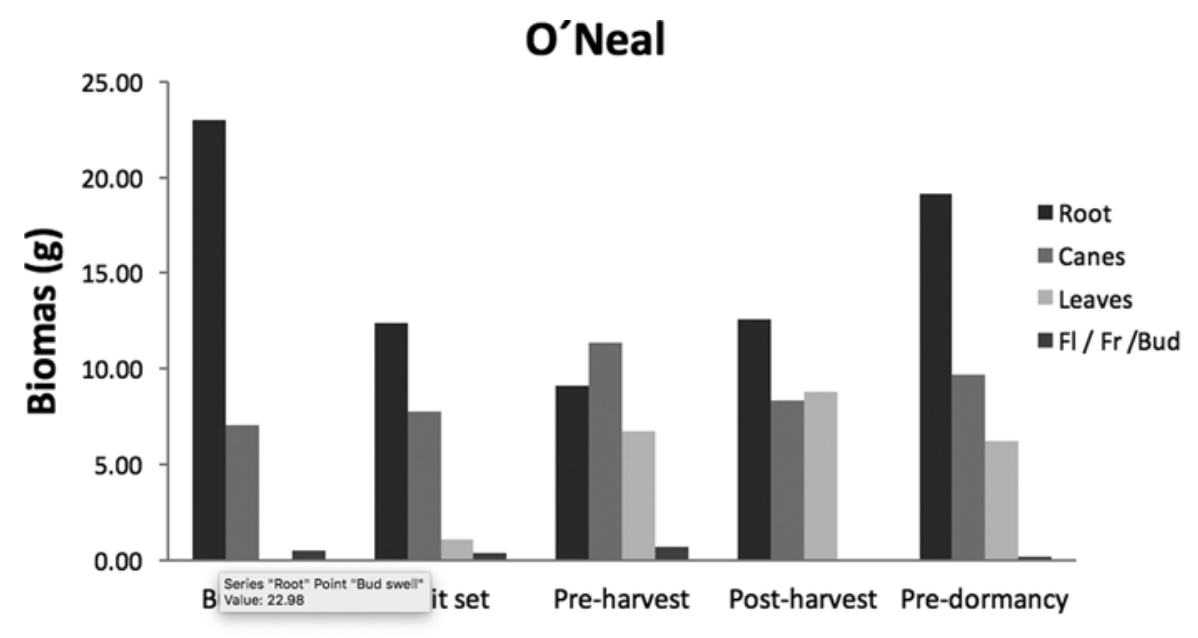

Fig. 1. Plant organs biomass $\left(g\right.$ organ $\left.^{-1}\right)$ in two years old plants of southern highbush blueberry at different phenological stages. a) O'Neal cultivar and b) Star cultivar.

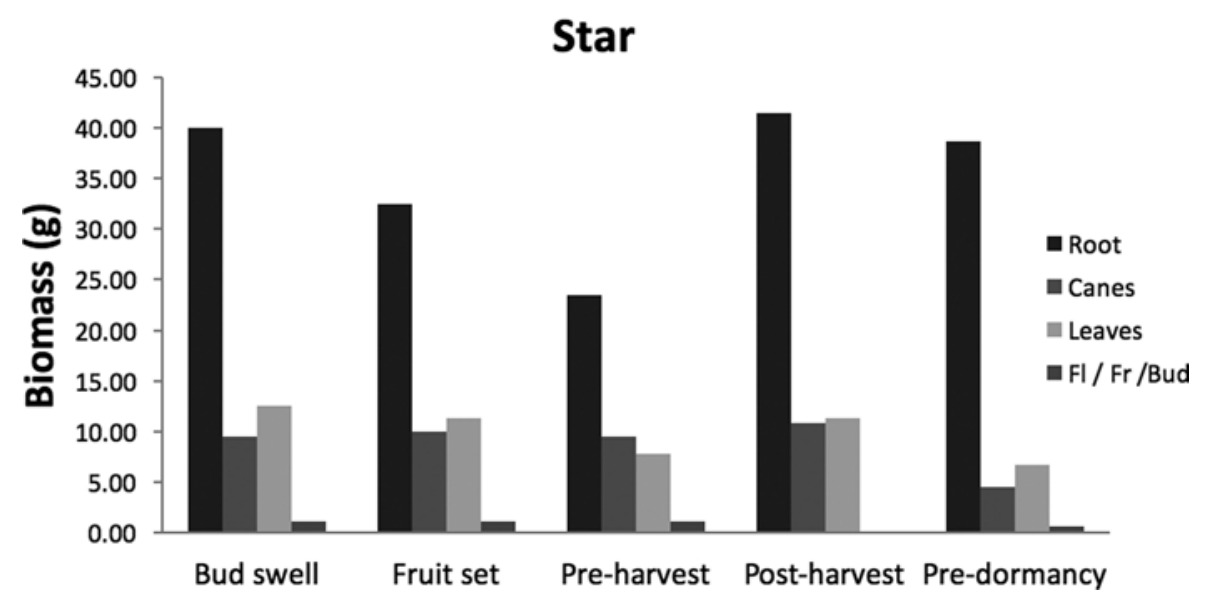

\section{Results}

\subsection{Biomass production}

ÓNeal plants showed lowertotal DM than Star plants (average of $29.01 \mathrm{~g}$ and $54.26 \mathrm{~g} /$ plant respectively). Fig. 1 shows DMvalues of different tissues in both cultivars for all treatments. Roughly, roots were the tissue with the higher DM followed by canes and leaves, while flowers and/or fruits were the tissue with lower DM in both cultivars. The dynamic of DM accumulation shows that ÓNeal roots lose DM from bud swell to pre harvest but then it recovers DM until pre-dormancy (Fig. 1). Canes DM increased from vegetative bud break to pre-harvest (end of the first vegetative growth), where they reachedmore DM than roots. Star plants showeda similar pattern than ÓNeal for roots DM, but canes and leaves where stable through the phenological stages. RootsDM dynamics was similar to ÓNeal although it doubled the DM in canes and leaves. Again, flowers or fruits are the tissue with lower DM (Fig. 1).

Considering the average accumulated DM (all samplings) (Fig. 2), roots represented $50 \%$ and canes $29 \%$ of total biomass accumulated in ÓNeal cultivar. Conversely, Star roots represented $65 \%$ of total DM while canes only $17 \%$. ÓNeal fruits were three times smaller than Star fruits $(0.20$ and $0.66 \mathrm{~g}$, respectively) but fruits represented $2 \%$ of the total DM in both cultivars. Definite fruits only were harvested in T3 treatment. It is important to indicate that plants are 2 years old and no high yields could be expected (Fig. 2).

\subsection{Total nitrogen content at different organs}

Table 1 shows macro and micro nutrients concentrations in leaves. Except for $\mathrm{N}$ and $\mathrm{Fe}$, all nutrients were found in higher concentrations in ÓNeal than in Star leaves.

Total $\mathrm{N}$ content ( $\mathrm{N}$ concentration $\mathrm{x}$ total biomass) is globally lower in O'Neal plants than in Star ones. The N content was different between vegetative and reproductive stages in the whole plant as well as inthe organs. $\mathrm{N}$ in roots was significantly higher $(\mathrm{p}<0.05)$ than in the other organs at bud swell but decreased as the productive cycle proceeds. Nitrogen content in roots after harvest increased and exceeded the $\mathrm{N}$ content at the start of the reproductive and vegetative cycle (Table 2).

Canes $\mathrm{N}$ content in both cultivars, tend to increase as the productive season proceed, and reached a maximum peak at the end of the cycle, when plants entered in dormancy. This trend was more evident in ÓNeal plants. The $\mathrm{N}$ in leaves showed a divergent pattern with a trend to increase in ÓNeal but to decrease in Star along the reproductive and vegetative cycle (Table 2). Buds, flowers and fruits, despite their high $\mathrm{N}$ concentration (21\% and 6\% in ÓNeal and Star flowers, respectively), are the tissues with lower $\mathrm{N}$ content and tend to decrease as the crop cycle proceed. The flowers had more $\mathrm{N}$ content than set fruits, and those more than mature fruit (Table 2).

The average of all samplings shows a general picture (Fig. 2). Root accumulated is the tissue with the highest $\mathrm{N}$ content in both cultivars followed by leaves. ÓNeal plants showed two times more $\mathrm{N}$ accumulated in canes than Star plants (16\% and $8 \%$, respectively). Fruits contained the lowest quantity of $\mathrm{N}$ in both cultivarsand were similar between them. 


\section{a) O’Neal}

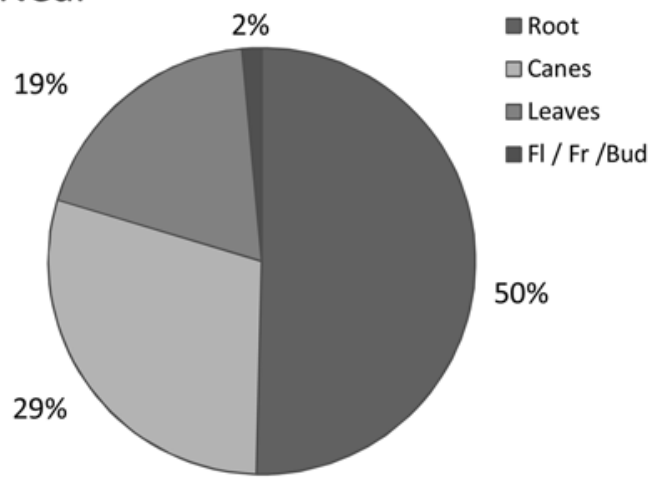

b) Star

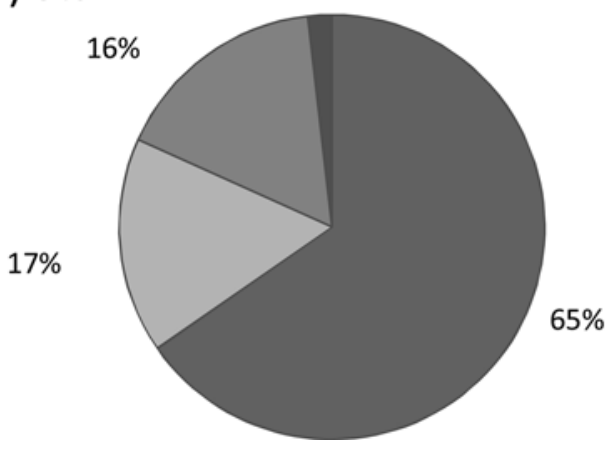

Fig. 2. Average biomass partitioning (\% dry weight) at different plant organs in a) O'Neal and b) Star two years old southern highbush blueberry plants.

Table 1

Nutrients status in two years old southern highbush blueberry, ÓNeal and Star plants determined in leaves by December after harvest. (Macronutrients, $\mathrm{gkg}^{-1}$; Micronutrients, $\mathrm{mgkg}^{-1}$ ).

\begin{tabular}{lllllll}
\hline Cultivar & $\mathrm{N}$ & $\mathrm{P}$ & $\mathrm{K}$ & $\mathrm{Ca}$ & $\mathrm{Mg}$ & $\mathrm{S}$ \\
\hline ÓNeal & 23.4 & 2.0 & 15.7 & 5.2 & 3.3 & 2.9 \\
Star & 21.4 & 1.3 & 8.7 & 3.2 & 2.3 & 1.6 \\
& $\mathrm{~B}$ & $\mathrm{Cu}$ & $\mathrm{Fe}$ & $\mathrm{Mn}$ & $\mathrm{Zn}$ & - \\
ÓNeal & 196 & 22 & 123 & 367 & 78 & - \\
Star & 177 & 14 & 222 & 100 & 61 & - \\
\hline
\end{tabular}

\subsection{Nitrogen distribution in plants according to fertilization time}

Nitrogen accumulation in plants varied as fertilization was applied at different phenological stages. Comparing cultivarsperformance, when plants were fertilized at bud swell, ÓNeal plants accumulated $40 \%$ more $\mathrm{N}$ in absolute terms, than Star plants. More ahead, while in ÓNeal plants, at bud swell, the NdfF was higher in flowers, followed by canes and roots (Fig. 3) (Duncan test $p<0.05$ ), and in Star plants
Nddf in O'Neal

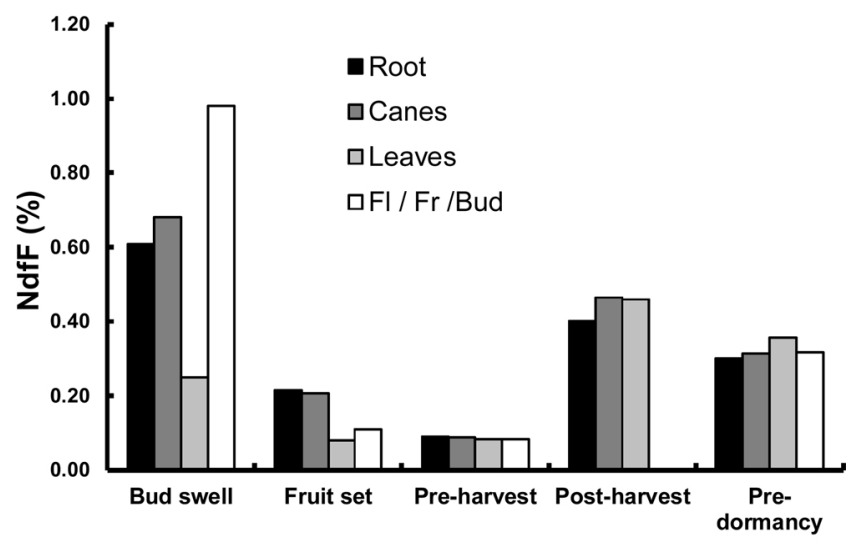

\section{Nddf in Star}

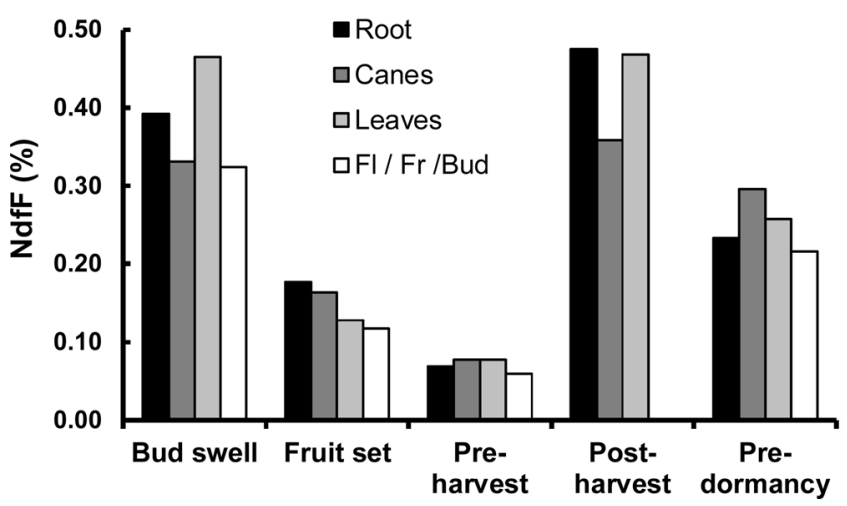

Fig. 3. NdfF (\%) in O'Neal and b) Star highbush blueberry cultivar components at different phonological stages of ${ }^{15} \mathrm{~N}$ fertilization.

NdfF was more homogenously distributed among organs (Fig. 3). The higher NdfF concentration found in leaves and roots was significantly higher than in flowers and canes $(\mathrm{p}<0.05)$ (Fig. 3). Flowers in both cultivars received the largest amount of $\mathrm{N}$ when compared with fruits or fruit buds(p < 0.05). Furthermore, the NdfF in flowers was $21.4 \%$ and $6 \%$ for ÓNeal and Star plants, respectively.

Comparing across fertilization dates, it is observed that ÓNeal canes received a larger amount of $\mathrm{NdfF}$ when applied at bud swell than when $\mathrm{N}$ was applied at post-harvest. In Star canes, NdfF when $\mathrm{N}$ was applied at bud swell, post-harvest or pre-dormancywas similar (Duncan test $\mathrm{p}>0.05)$.

In ÓNeal, the maximum NdfF in roots was found at bud swell application, and then in post-harvest, but Star roots accumulated more NdfF when $\mathrm{N}$ was applied inpost-harvest than at bud swell $(\mathrm{p}<0.05)$ (Fig. 3).When $\mathrm{N}$ was applied at bud swell, NdfF found at ÓNeal plant

Table 2

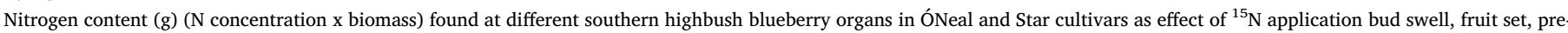
harvest, post-harvest and pre-dormancy.

\begin{tabular}{|c|c|c|c|c|c|c|c|c|}
\hline \multirow[t]{2}{*}{ Treatments $\left({ }^{15} \mathrm{~N}\right.$ application) } & \multicolumn{4}{|l|}{ ÓNeal } & \multicolumn{4}{|l|}{ Star } \\
\hline & Roots & Canes & Leaves & Flower, fruit or buds & Roots & Canes & Leaves & Flower, fruit or buds \\
\hline Bud swell & 0,265 & 0,049 & & 0,024 & 0,433 & 0,073 & 0,732 & 0,057 \\
\hline Fruit set & 0,098 & 0,049 & 0,085 & 0,006 & 0,256 & 0,058 & 0,242 & 0,018 \\
\hline Pre-harvest & 0,075 & 0,057 & 0,121 & 0,005 & 0,190 & 0,050 & 0,123 & 0,007 \\
\hline Post-harvest & 0,185 & 0,078 & 0,189 & - & 0,709 & 0,037 & 0,180 & - \\
\hline Pre-dormancy & 0,369 & 0,106 & 0.137 & 0,001 & 0,540 & 0,101 & 0.114 & 0,015 \\
\hline
\end{tabular}


was globally higher than when it was applied at fruit set. Nitrogen concentration was higher in fruits (Duncan test, significance level 5\%).

In Star the NdfF distribution was similar for roots and canes, but fruit was the last sink ( $\mathrm{p}<0.05$ ) (Fig. 3). Fertilizer application in preharvest show a lower $\mathrm{N}$ accumulation than in previous applications and the NdfF distribution among plant organs was homogeneous in both cultivars.

ÓNeal and Star plants fertilized at post-harvest and pre-dormancy had more time to accumulate $\mathrm{N}$, however, studied cultivars showed differences in NdfF accumulation. O'Neal plants showed a homogenous $\mathrm{N}$ distribution among organs. Conversely, Star plants showed significatively less NdfF in canes compared with roots and leaves ( $p<0.05$ ) (Fig3). In post-harvest fertilization, ÓNeal leaves accumulated more NdfF than in pre-dormancy or bud swell fertilization $(\mathrm{p}<0.05)$. Star leaves also accumulated more NdfF at post-harvest fertilization than in pre-dormancy, but this accumulation it is not different from that of bud swell application ( $p<0.05$ ) (Fig. 3).

\subsection{Nitrogen recovery}

The recovery of $\mathrm{N}$ from fertilizer was higher in Star than in ÓNeal plants, especially when was fertilized at bud swell. The higher proportion of $\mathrm{N}$ recovered was at post-harvest, followed by pre-dormancy nitrogen application, but at those times, the plants were in the containers with $\mathrm{N}^{15}$ for longer time (around 3 month), different from the other fertilization times, where the plants were only three weeks in contact with $\mathrm{N}^{15}$ (Table 3 ). Other time of high recovery was bud swell fertilization, especially in variety Star.

The recovery of $\mathrm{N}$ inÓNeal plants fertilized in bud swell were $46 \%$ in roots, $42 \%$ in canes and $21 \%$ in leaves and in Star plants were $36 \%$, $42 \%, 8 \%$, respectively and $6 \%$ in flowers. When fertilizer was applied at post-harvest that ratio was $27 \%$ in roots, $49 \%$ in canes and $23 \%$ in leaves in ÓNeal plants, while in Star plants NdfF were 27\%, 43\% and $29 \%$, respectively. In pre-dormancy fertilization, the ratio in ÓNeal cultivar was $15 \%$ in roots, $28 \%$ in canes, $23 \%$ in leaves and $10 \%$ in buds, while Star plants the ratio was $16 \%, 32 \%, 15 \%$ and $16 \%$, respectively. The sinks receiving the non-recovery $\mathrm{N}$ were not assessed in the present research.

\section{Discussion}

In general terms, most macro and micro nutrients showed adequate plant nutritional balance in both cultivars, according to the standards from Hanson and Hancock (1996) and Hart et al. (2006). The exceptions were relatively low $\mathrm{N}$ and relatively high potassium and boron concentrationfor blueberries leaves, in both cultivars, and magnesium and sulfur in ÓNeal plants.

Roots relative importance in the total plant biomass, and its dynamics across treatments was similar to other blueberry groups (Retamales and Hanson, 1989). Roots carbohydrates reserves moved toward the rest of the plants in spring, when all process led to fruit development (Birkhold and Darnel, 1993). This is clearly seen when at pre-harvest stage ÓNeal roots biomassfall down more than biomass of canes. At this time carbohydrates are required by fruits and enlarging

Table 3

Nitrogen $\left(\mathrm{N}^{15}\right)$ recovery $(\%)$ at blueberry plants related to fertilization time and cultivar.

\begin{tabular}{lll}
\hline Treatments $\left({ }^{15} \mathrm{~N}\right.$ application) & \multicolumn{2}{l}{$\mathrm{N}$ recovered (\%) } \\
\cline { 2 - 3 } & ÓNeal & Star \\
\hline Bud swell & 10.3 & 29.7 \\
Fruit set & 7.1 & 13.2 \\
Pre-harvest & 6.2 & 10.6 \\
Post-harvest & 40.8 & 42.7 \\
Pre-dormancy & 14.7 & 21.8 \\
\hline
\end{tabular}

leaves, indicating roots reserves dependency. According to Tromp (1983), roots respiration must also be taken into account since it compromise $25 \%$ to $45 \%$ of plant biomass.

Plants grown in South America show vegetative growth after harvest, so the photosynthates generated for them, are accumulated mainly in roots for the next productive period. In our case, the radical biomass recovery was less intense in ÓNeal plantssince root biomass at the end of vegetative cycle waslower than roots biomass at the beginning of the cycle. Thisfact explains why ÓNeal plants weakengradually, affecting productive life and yields. Also, a reduction in biomassof ÓNeal canes after harvest were found, which could be linked to reserve movements toward roots which is other sign of reserves dependence of this cultivar for flowering and initial fruit growth. To avoid this problem, several management practices were established, like early harvest (Borda, 2015) or adequate pruning (Pescie et al., 2011a). Conversely, Star plants are less dependent from roots reserves for initial growth stages, allowing plant reserves to maintain a larger root biomass, which ensure more resources during its productive life. By the end of the growth period, Star canes and roots biomass were $22 \%$ and $50 \%$ higher than in ÓNeal, respectively. Probably, root growth in Star is less dependent from vegetative growth than ÓNeal plants.

The higher $\mathrm{N}$ content found in roots agree in general with the results of Birkhold and Darnel (1993) in REB, although there were some differences. $\mathrm{N}$ in roots of the REB was constant throughout productive period while in SHB roots $\mathrm{N}$ decreases until harvest and then recovers. This difference could be related to the smaller root system of SHB cultivars in relation to REB (Trehane, 2004). Also, SHB have a shorter fruit development period, with a concentrated demand of $\mathrm{N}$ from roots until harvest.

In our studied ÓNeal and Star plants, flowering and fruit growth occurred mainly thanks to reserves accumulated in roots, like in other fruit species as sweet cherry (San-Martino et al., 2010) or pear (Sanchez et al., 1990). In those crops flowering and initial fruit development occurs without active leaves as in ÓNeal, but not in Star plants. Other source of photosynthates is the photosynthesis carried out for the proper fruit. According to Birkhold et al. (1992) photosynthesis from blueberry fruits could contribute with up to $85 \%$ of carbohydrates of its initial requirement.

Star plants showed a decrease in $\mathrm{N}$ content in canes from flowering to harvest, as Birkhold and Darnel (1993) found in rabbiteye cultivars. Conversely,ÓNeal plants keep $\mathrm{N}$ level constant until harvest and then increase.

ÓNeal leaves are an important N sink after harvest, in agreement with results found in pear (Tagliavini et al., 1997; Neto et al., 2008) and in highbush blueberry (Throop and Hanson, 1997).N contentin Starleavestent to decrease as in rabbiteye blueberry (Birkhold and Darnel, 1993) and peach (Rufat and Dejong, 2001).Nitrogen content in ÓNeal and Star reached a maximum at the end of the season as it was found in HBB by Bañados et al. (2012). In ourstudied cultivars the $\mathrm{N}$ content in fruitswas similar to the $\mathrm{N}$ content found in blackberry (Naraguma et al., 1999), rabbiteye blueberry (Birkhold et al., 1992) and highbush blueberries (Retamales and Hanson, 1989).

The NdfF decreased toward harvest in both cultivars and increased afterward, as in rabbiteye (Birkhold and Darnel, 1993) and plum (Weinbaum et al., 1978; Weinbaum et al., 1992). Weinbaum et al. (1992) suggested the low $\mathrm{N}$ absorption toward fruit maturation could be caused by the reserves derivation from different plant organs to the fruit. The highest rate of $\mathrm{N}$ absorption was registered during flowering in our both cultivars, even in ÓNeal plants which were still without functional leaves.This result agrees with that found in cranberry (Hart et al., 1994) and sweet cherry (Azarenko et al., 2008). Low N absorption at bloom were found in highbush blueberry (Troop and Hanson, 1997) and other fruit like plum (Weinbaum et al., 1978), pears (Sanchez et al., 1990) and peach (Muñoz et al., 1993). In some of those cases, results were attributed to a low transpiration rate due to absence of leaves. Tagliavini et al. (1997) found $12 \%$ of NdfF contribution at 
bloom in pear. In our study, ÓNeal plants showed a higher NdfF contribution $(21 \%)$ than Star $(6 \%)$.

Leaves are the tissue with higher $\mathrm{N}$ demand at bloom and new vegetative growth in Star plants, coincident with results found by Birkhold and Darnel in rabbiteye blueberries (1993), Retamales and Hanson (1989) in highbush blueberry and Sanchez et al. (1990) in pear. ÓNeal plants at this time had fruit development in advanced stage, which is a more important sink than leaves. After harvest, leaves area more important $\mathrm{N}$ recipient. This results is different from results found in HBB and REB (Birkhold et al., 1992; Childers and Lyrene, 2006), and could be explained by the early harvest time for SHB, that allow a longer time for second vegetative growth until dormancy (Pescie and Lopez, 2007; Pescie et al., 2011b).

Nitrogen recovery when fertilized at fruit set and pre-harvest in ÓNeal was not very different from results found by Troop and Hanson (1997) in HBB, but at bud swell fertilization we found a much higher recovery compared to results found by those authors and Bañados et al. (2006a, 2006b), also in HBB. Post-harvest application allows a high $\mathrm{N}$ recovery in ÓNeal and Star plants, coincidently with results found in LBB (Eaton and Patriquin, 1990). Retamales and Hanson (1989) found a lower $\mathrm{N}$ recovery in mature $\mathrm{HBB}$ plants by the end of the growing season and the same result was found by Bañados et al. (2006a, 2006b).

Finally, we can assume that ammonia volatilization was a small pathway for the non-recovery $\mathrm{N}$, due to the low $\mathrm{pH}$ of the substrate (Watson et al., 1994). Accumulation of residual nitrate probably was low for the same reason. Other sinks for the applied $\mathrm{N}$ (denitrification and other minor sinks), do not appear to be important in present case, like indicated by Rimski-Korsakov et al. (2008) for pot soils. Main sink for the applied $\mathrm{N}$ not used by the plants may be the incorporation into the live or dead soil organic fraction. However, the $\mathrm{N}$ accumulation in this fraction could not be permanent, as any event changing soil characteristics, like $\mathrm{pH}$, water content and so on, would lead to an important loss of the $\mathrm{N}$ accumulated in the organic matter and retained by the soil.

\section{Conclusions}

Essayed southern highbush blueberry cultivars showed a globally different behavior from others blueberry groups, respect to nitrogen dynamics. Also, both cultivars studied showed large differences among them, i.e their different root biomass performance. Our results shown that at bud swell and post-harvest, $\mathrm{N}$ is absorbed in more amounts and distributed selectively to the stronger sinks. Nitrogen fertilization at bud swell is effective, even for the ÓNeal cultivar that present floral bud break in absence of leaves. Nitrogen absorbed at that moment goes to flowers and then is used for fruit set and first stages of fruit development. On the other hand, post-harvest fertilization contribute $\mathrm{N}$ for summer vegetative growth which would influence next year floral buds development. Beside storage nitrogen would lead to the improved floral behavior for next year. Nitrogen losses risk is lower at post-harvestfertilization.

\section{Acknowledgments}

Authors thank the Universidad Nacional de Lomas de Zamora (LomasCyT) and Universidad de Buenos Aires (UBACyT) for financial support.

\section{References}

Abbott, J.E., Gough, R.E., 1987. Seasonal development of highbush blueberry roots under sawdust mulch. J. Am. Soc. Hortic. Sci. 112, 60-62.

Azarenko, A.N., Chozinski, A., Brutcher, L., 2008. Nitrogen uptake efficiency and partitioning in sweet cherry is influenced by time of application. Acta Hortic. 795, $717-721$.

Bañados, M.P., Bonomelli, C., Gonzales, J., Jiullerat, F., 2006a. Dry matter, nitrogen, potassium and phosphorus partitioning in blueberry plants during winter. Acta Hortic. 715, 443-448.
Bañados, M.P., Strik, B., Righetti, T., 2006b. The uptake and use of 15N-nitrogen in young and mature field-grown highbush blueberries. Acta Hortic. 715, 357-364.

Bañados, M.P., Strik, B.C., Bryla, D.R., Righetti, T.L., 2012. Response of highbush blueberry to nitrogen fertilizer during field establishment: I. Accumulation and allocation of fertilizer nitrogen and biomass. HortScience 47, 648-655.

Birkhold, K.T., Darnel, R.L., 1993. Contribution of storage and currently assimilated nitrogen to vegetative and reproductive growth of rabbiteye blueberry. J. Am. Soc. Hortic. Sci. 118, 101-108.

Birkhold, K.T., Koch, D.E., Darnel, R.L., 1992. Carbon and nitrogen economy of developing rabbiteye blueberry fruit. J. Am. Soc. Hortic. Sci. 117, 139-145.

Borda, M.P., 2015. Efecto De La Cosecha Temprana Sobre El Crecimiento De La Planta Y El Rendimiento En Arándanos Altos Del Sur (Vaccinium Corymbosum híbrido Interespecífico) Mag. Tesis. Universidad de Buenos Aires, Argentina 78 p.

Childers, N., Lyrene, P., 2006. Blueberries for Growers, Gardeners, Promoters. E.O Painter Printing, Gainesville, FL, USA.

Chuntanaparb, N., Cummings, G., 1980. Seasonal trends in concentration of nitrogen, phosphorus, potassium, calcium, and magnesium in leaf portions of apple, blueberry, grape, and peach. J. Am. Soc. Hortic. Sci. 105, 933-935.

Conradie, W.J., 1986. Utilization of nitrogen by the grape-vine as affected by time of application and soil type. South. Afr. J. Enol. Vitic. 7, 76-83.

Hanson, E., Retamales, J.B., 1992. Effect of nitrogen source and timing on highbush blueberry performance. HortScience 27, 1265-1267.

Hart, J.M., Poole, A.P., Strik, B.C., Christensen, N.W., 1994. Nitrogen Fertilizer Rate and Timing Trials in Oregon. Research Gate Publications. https://www.researchgate.net/ publication/268361665_Nitrogen_fertilizer_rate_and_timing_trials_in_Oregon.

Hart, J.M., Strik, B., White, L., Yang, W., 2006. Nutrient Management for Blueberries in Oregon. Oregon State University. Extension Service. http://ir.library.oregonstate. edu/xmlui/bitstream/handle/1957/20444/em8918.pdf .

International Atomic Energy Agency, 2001. Use of isotope and radiation methods in soil and water management and crop nutrition. Training Course Series 14. IAEA, Vienna.

Kirschbaum, D.S., Rivadeneira, M.F., 2011. La Cadena Del Arándano En La Argentina INTA. http://inta.gob.ar/sites/default/files/script-tmp-cadena_arandano.pdf.

Kraimer, R.A., Lindemann, W.C., Herrera, E.A., 2001. Distribution of 15N-labeled fertilizer applied to pecan: a case study. Hortscience 36, 308-312.

Lang, G.A., 1993. Southern highbush blueberries: physiological and cultural factors important for optimal cropping of these complex hybrids. Acta Hortic. 346, 72-80.

Loescher, W.H., McCamant, T., Keller, J.D., 1990. Carbohydrate reserves, translocation, and storage in woody plant roots. Hortscience 25, 274-281.

Lyrene, P.M., Williamson, J.G., 1997. Highbush blueberry varieties for Florida. Proc. Fla. State Hortic. 110, 171-174.

Merhaut, D., Darnell, R., 1995. Ammonium and nitrate accumulation in containerized southern highbush blueberry plants. HortScience 30, 1378-1381.

Mohadjer, P., Strik, B.C., Zebarth, B.J., Righetti, T.L., 2001. Nitrogen uptake, partitioning and remobilization in' Kotatá blackberry in alternate-year production. J. Hort. Sci. Biotechnol. 76, 700-708.

Muñoz, N., Guerri, J., Legaz, F., Primo-Millo, E., 1993. Seasonal uptake of 15N-nitrateand distribution of absorbed nitrogen in peach trees. Plant Soil 150, 263-269.

Naraguma, J., Clark, J.R., Norman, R.J., Mc New, R.W., 1999. Nitrogen uptake and allocation by field-grown 'Arapaho' thornless blackberry. J. Plant Nutr. 22, 753-768.

Neto, C., Carranca, C., Clemente, J., de Varennes, A., 2008. Nitrogen distribution, remobilization and re-cycling in young orchard of non-bearing 'Rocha' pear trees. Sci. Hort. 118, 299-307.

Percival, D.C., Privé, J.P., 2002. Nitrogen formulation influences plant nutrition and yield components of lowbush blueberry (Vaccinium angustifolium Ait.). Acta Hortic. 574, $347-353$.

Pescie, M., Lovisolo, M., De Magistris, A., Strik, B., López, C., 2011a. Flower bud initiation in southern highbush blueberry cv. O'Neal occurs twice per year in temperate to warm-temperate conditions. J. Appl. Hortic. 13, 8-12.

Pescie, M.A., Borda, M.P., Fedyszak, P., Lopez, C., 2011b. Efecto del momento y tipo de poda sobre el rendimiento y calidad del fruto en arándanos altos del sur (Vaccinium corymbosum) var. ÓNeal en la provincia de Buenos Aires. Revista de Investigaciones Agrarias INTA 37, 268-274.

Rempel, H.G., Strik, B.C., Riguetti, T.L., 2004. Uptake, partitioning and storage of fertilized nitrogen in red ruspberry as affected by rate and timing of application. J. Am. Soc. Hort. Sci. 129 (3), 439-448.

Retamales, J.B., Hanson, E.J., 1989. Fate of N15-labeled urea applied to mature highbush blueberries. J. Am. Soc. Hortic. Sci. 114, 920-923.

Retamales, J.B., Hanson, E.J., 1990. Effect of nitrogen fertilizers on leaf and soil nitrogen levels in highbush blueberries. Commun. Soil Sci. Plant Anal. 21, 2067-2078.

Rufat, J., Dejong, T.M., 2001. Estimating seasonal nitrogen dynamics in peach trees in response to nitrogen availability. Tree Physiol. 21, 1133-1140.

SAS Institute Inc., 2012.

Sahrawat, K.L., 2008. Factors affecting nitrification in soils. Soil Sci. Plant. Anal. 39, 1436-1439.

San-Martino, L., Sozzi, G.O., San Martino, S., Lavado, R.S., 2010. Isotopically labelled nitrogen uptake and partitioning in sweet cherry as influenced by timing of fertilizer application. Sci. Hortic. 126, 42-49.

San Martino, L., San Martino, S., Lavado, R.S., 2014. Soil nitrate profiles and the risk of nitrate leaching in sweet cherry orchards subjected to different management schemes. Int. J. Fruit Sci. 14, 424-436.

Sanchez, E., Righetti, T., Sugar, D., Lombard, P., 1990. Seasonal differences and soil texture alter uptake of newly absorbed nitrogen in field-grown pear trees. J. Hortic. Sci. 65, 395-400.

Strik, B., Yarborough, D., 2005. Blueberry production trends in North America 1992-2003, and predictions for growth. Hortechnology 15, 391-397.

Tagliavini, M., Quartieri, M., Millard, P., 1997. Remobilized nitrogen and root uptake of 
nitrate for spring leaf growth, flowers and developing fruits of pear (Pyrus communis L.) trees. Plant Soil 195, 137-142.

Tamada, T., 2000. Stages of rabbiteye and highbush blueberry fruit development and the associated changes in mineral elements. Acta Hortic. 574, 129-137.

Temminghoff, E.J.M., 2000. Methodology of chemical soil and plant analysis.

Wageningen Universiteit, Wageningen. The Netherlands.

Throop, P.A., Hanson, E.J., 1997. Effect of application date on absorption of $15 \mathrm{~N}$ by highbush blueberry. J. Am. Soc. Hortic. Sci. 122, 422-426.

Tromp, J., 1983. Nutrient reserves in roots of fruit trees, in particular carbohydrates and nitrogen. Plant Soil. 71, 401-413.

Vidal, I., Amaro, J., Venegar, A., 1999. Evolución estacional de nutrientes y estimación de la extracción anual en arándano ojo de conejo (Vaccinium ashei R.). Agricultura Técnica 59, 309-318.
Watson, C.J., Miller, H., Poland, P., Kilpatrick, D.J., Allen, M.D.B., Garrett, M.K., Christianson, C.B., 1994. Soil properties and the ability of the urease inhibitor N-(nButyl) thiophosphorictriamide (nBTPT) to reduce ammonia volatilization from surface-applied urea. Soil Biol. Biochem. 9, 1165-1169.

Weinbaum, S.A., Merwin, M.L., Muraoka, T.T., 1978. Seasonal variation in nitrate uptake efficiency and distribution of absorbed nitrogen in non-bearing prune trees. J. Amer. Soc. Hortic. Sci. 2, 112-121.

Weinbaum, S.A., Johnson, R.S., Dejong, T.T., 1992. Causes and consequences of overfereilization in orchards. Hort Technology 2, 212-221.

Williamson, J., Krewer, G., Pavlis, G., Mainland, C., 2006. Blueberry soil management, nutrition and irrigation. In: Childers, N., Lyrena, P. (Eds.), Blueberries. Dr. Childers Horticultural Publications, Gainseville, Florida, USA, pp. 60-74. 